\title{
Contributing Factors in Emergence and Growth of Chinese Grocery Own Brands
}

\author{
Wei Song, Ph.D. \\ School of Business and Economics, Thompson Rivers University \\ 900 McGill Road, PO Box 3010, Kamloops, V2C 5N3, BC, Canada \\ Tel: 1-250-828-5373/1-804-212-1545 E-mail: wsong@tru.ca
}

The research has been partially funded by the School of Business and Economics (SoBE) Research \& Project Awards and Research Enhancement Grant from Thompson Rivers University, BC Canada.

\begin{abstract}
The purpose of this study is to examine the possible contributing factors associated with the emergence and growth of Chinese own brands in the grocery sector. This sector represents one of the most rapidly growing market segments in the country. The main method adopted in this qualitative study was in-depth interviews with a panel of sixteen Chinese retail experts using Shanghai, China as the geographic focus. Shanghai is appropriate because it leads China as a trend-setting location due to its economic activity with the West. A technique of thematic analysis was employed in the analysis. Four factors associated with the emergence and growth of Chinese grocery own brands have been identified. The results from the study are intended to offer guidance for future studies in the area of grocery own brand research in China and to build a basis for developing own brand strategy in the non-Western markets. The implications, limitations and directions of the study are also discussed. The study contributes to the literature for the own brand research portfolio in the emerging markets.
\end{abstract}

Keywords: Chinese own brands, Grocery sector, Retailers, Non-Western markets

\section{Introduction}

Own brands, retailer owned products, once dominated by Western retailers, eventually have emerged and grown in the non-Western markets. These include Asian and Eastern European, as well African markets. The emergence and growth of grocery own brands in these markets creates new opportunities for both Western and non-Western retailers.

Although the extensive studies have been conducted, the findings are mainly from the Western markets while the data from the emerging markets are scarce as these markets are growing rapidly. An indication of the rapid growth of emerging markets is shown in the AC Nielson report, 2009, which indicates that the China market has more than 3.3 million fast moving consumer-goods (FMCG) stores nationally. Retail distribution will represent $60 \%$ of the total FMCG sales volume by 2015 . However, there remains a paucity of studies in this arena. In particular, the issue of why own brands have emerged and grown in the non-Western markets, such as China, has not been well addressed. This article aims to identify some possible factors which contribute to the emergence and growth of grocery own brands in China. The grocery sector is selected as this sector is one of the fastest growing market sectors in China (Wu and Deng, 2002; Hsu and Lai, 2008).This study contributes to:

- A clear understanding of the emergence and growth of own brands in non-Western markets.

- Expanding knowledge of the role played by own brands in the context of Chinese grocery chains.

- The limited but burgeoning body of literature and research on store-brand strategy in emerging markets.

The observations and conclusions are useful in the broader global context of own brand development and have the potential to contribute to own brand research in North American markets. Following a brief literature review pertaining to the factors leading to the emergence and growth of own brands in the Western markets, the methodology adopted in this study is explained. The results and findings from the expert interviews are presented. A number of potential managerial implications are also discussed. The limitations of the study and the directions of the further studies are explicated. 


\section{Literature review}

The success of own brand strategy is evidenced by the major grocery retailers, such as Tesco and Sainsbury (UK), Carrefour (France), Aldi (Germany), Wal-Mart (USA) and Loblaw (Canada) (Burt \&Mavrommatis, 2006; Pache, 2007). Substantial research has been conducted and four possible reasons contributed to the emergence and fast growth of grocery own brands in the Western market have been identified: Concentration, competition, technology innovation and legislation. These reasons have explained why Western own brands have emerged and how they have rapidly developed during the last 20 years. The first reason is retailer concentration. For example, in the UK, four major retailers, i.e., Tesco, Sainsbury, ASDA and Morrison have controlled about two thirds of the total UK food retail market shares (Fearne et al., 2005; Mintel, 2005) which represents a concentrated market (Hollingsworth, 2004) while UK has the most advanced own brand model (Wileman\&Jary, 1997). Based on the literature, concentration is one of the most important factors that contributes to the development of own brands (Economist, 1995; Davies, 1998; Hughes, 1996; Cooper \& Nelson, 2003; Dobson et al., 2003; AC Nielson, 2009). The retail concentration creates the incentives for the retailer to carry on own branded products (Tarzijan, 2003, 2004). Therefore there may be a linkage between retailers' concentration and own brand market shares (Wileman\&Jary, 1997; Steenkamp\&Dekimpe, 1997) as the retailers can realize the economy of scale to maintain lower costs due to their proportionately larger size (Davies, 1998; Hyman, Kopf \& Lee, 2010). However, controversies exist as some researchers have contended that market concentration is not always associated with the growth of retailer brand penetration (e.g., Baden-Fuller, 1984; Burt, 2000). Thus, making the simple correlation between the growth of a retailer's market share and own brand penetration may be misleading (Burt, 2000; Dawson, 2001a, b).

The second reason is the competition. Competition is the most fundamental and most complicated factor that directly stimulates the own brand emergence and growth. Developing an own brand strategy is the means to create differentiation and uniqueness, which is the key to winning the competition for all retailers (Corstjens, J., \& Corstjens, M., 1995; Lui \& Wang, 2008; Groznik \& Heese, 2010). There are three types of competition that affect the own brand development (Laaksonen, 1994): The competition from manufactures' brands; from other retailer's brands, and from discounter's unknown labels. A prevalent view is that intense competition against national brands in retail marketing is the major reason, and specifically, the initial reason for the significant growth of the own brands (Burt \& Sparks, 1994; Hoch, 1996; Cotterill et al., 2000; Burt, 2000; Dawson, 2001; McGoldrick, 2002, Tarzijan, 2004; Business Insights, 2005; Amrouche\&Zaccour; 2007). This view holds that retailers develop own brands because own brands present a "formidable source" of competition with national brands (Hoch \&Banerji, 1993). Starting in the mid 1990s, the Western retailers, e.g., UK grocers began to enhance the premium own brand ranges, which most negatively and directly impacted the market share of manufacturers' brands (Nandan\& Dickinson, 1994; Jonas \& Roosen; 2005). The competition among retailers is the second type related to own brand emergence and growth in the UK (Laaksonen, 1994; Hughes, 1996; Burt 2000). Western retailers not only compete with national brands, but also against rival retailers' brands. Building differentiated brands from other retailers is the most effective weapon in competing against rival retail brands (Fernie \& Pierrel, 1996; Burt, 2000; Ward et al., 2002; Verhoef, Nijssen, \& Sloot., 2002; Colla\& Dupuis, 2002; Ailawadi \& Harlam, 2004). The third type of competition with own brands comes from the discounters. These emerging discount stores, e.g., Aldi, Netto, and Lidl, represent a certain degree of threat to major grocery chains (Laaksonen, 1994; Business Insights, 2003) as they have made considerable progress in the Western grocery market (Hogarth-Scott \& Rice, 1994; Laaksonen, 1994; Burt, 2000). Therefore, in the middle 1990s, the UK own brand strategy refocused on building discount brands by taking a more price-conscious approach in order to compete with discounters (Corstjens, \& Corstjens, J., 1995; Hughes, 1996; Corstjens \& Lal, 2000). As a result, the Western retailers, e.g., UK retailers accordingly improved their value-line products as the low-end of their existing own brand range, which primarily aimed at discounters.

The third reason is technology innovation. The introduction of the new channels like DTC selling for manufacturers and new data collection mechanisms, such as radio-frequency identification (RFID) technology have the significant influence on the retailing innovation and the production of own brands (Larson et al. 2005; Hui, Fader \& Bradlow, 2009a, b). Especially in the food industry, technology has a large impact on grocery retail products as technology continues to enhance the retailers' innovative ability, which has directly accelerated the pace of retailer own brand development (Omar, 1995; Dawson, 1999; Keynote, 2003; Tarzijan, 2003). Technology strengthens the grocery retailers' capabilities to produce more sophisticated products, which have previously been dominated by the manufacturers (Omar, 1994). Technology has changed the own brand status from the unsophisticated and lower quality alternatives to the sophisticated products (Burt \& Davis 1999; Veloutsou, Gioulistanis, \& Moutinho, 2004). Technology and innovation narrow the gap between own brands 
and national brands for quality, sophistication and responsiveness to the rapidly changing consumer needs (Veloutsou et al., 2004; Consuegra, 2006; Francis, 2009).

The fourth reason is related to legislation. Changes in the legal system have also direct influence on manufacturer-retailer relationship (Horng\& Chen, 2007; Ailawadi, et al., 2010). It is very relevant to own brand emergence and growth. This is especially a case in the UK where the legal system has favored to retailers (Bhasin et al., 1995). In the UK, legislation does not constrain major grocery chains; therefore, these retailers are allowed more autonomy in their operations, including the own brand process (Hughes, 1996). Under British law, UK retailers can gain three advantages during the process of building retailers' brands: Protect themselves from manufacturers, defend themselves against accusations of imitating national brands, and preserve their own interests over the consumers (Hughes, 1996; Marsden \& Wrigley, 1996). Thus, the retailers have been in a position to control and monitor the whole process of own brand production (Collins \& Burt, 2003). The extant studies have explained the possible factors associated with the grocery own brand emergence and growth in the Western market which has provided the guideline for further investigation.

\section{Methodology}

The objective of this study is to examine the perceptions from retail experts on the causes of Chinese own brand emergence and growth. The research question sought was: Why have Chinese own brands emerged and grown? A qualitative design is selected as we address the question of "why", a qualitative approach usually serves well (Yin, 1994; Daymon, \& Holloway, 2004) while the statistical model may not be applicable (Omar, 1996).

The main research method in this qualitative study is the semi-structured interviews with a group of retail experts as the aim of this type of the interviews is to gain the perspectives of the interviewees so that the investigated topics could be explored (Daymon\& Holloway, 2004). The interviewees include the senior managers and consultants as well as a selection of Chinese professors. A panel of 16 retail experts was interviewed. Ten of them were senior managers from the six top chain stores with variety of ownerships. The selection of these six retail chains was based on the recommendation made by the Secretary of the Shanghai Chain Store Association. Three senior consultants chosen in grocery sector were interviewed as they were highly recommended by the executives interviewed. These consultants have been constantly working with the top retailers to develop retail marketing strategy; including building Chinese own brands. The list of three professors was composed by the author through surveying Chinese literature via a key academia search engine; i.e., "QingHuaTongfang" provided by a research university in Shanghai. All of these professors have a high research profile and are well-known scholars in China. They have been conducting marketing research for over two decades. Some of their studies are in the field of retailing management and own brand strategy. In China, retailing study is under the department of marketing for most of the universities and the research in Chinese own brands is still very limited (P1, P2 and P3). Table 1 presents the participants of the interviews.

The language employed during the interviews mainly was Mandarin, the official language in China. Shanghainese, a dialect of China, was used when conducting interview with a senior consultant who preferred to use Shanghainese to express his opinions. English was also considerably employed during the interviews with the professors when discussing some theoretical concepts as two of these professors received their PhDs from US universities and the other one has solid English language skills.

Both off-site and on-site note taking methods were used as some informants were uncomfortable with the note-taking during the interview. Especially for the interviews with the senior managers, verbatim note-taking was strongly discouraged. Interview notes were taken initially in Chinese, which later were translated into English. The interviews with the managers were conducted in their offices and local restaurants. The interviews with the consultants and professors were in their offices. An average interview time was around 45 minutes.

Data analysis were performed, including three phases in employing thematic analysis (Boyatzis, 1998): First, the themes were developed from the raw data of the informants by taking inductive approach, categorizing the codes in comparing to the prior research findings; i.e., four reasons of own brand emergence and growth in the Western market. Second, new categories of the codes were created, which were not matched with the existing themes. Third, the internal validity and external validity of coding was examined. The former was achieved by the member checking process carried out at the end of each interview. The latter was completed by inviting two experienced researchers to review the results to ensure the transferability of the coding.

In order to ensure the quality of the field-note translation, a back-translation method was implemented via language software translation and consultation with an English professor in Shanghai. It must be mentioned that anonymity was required by all the interviewees, which made it difficult to use direct quotes in this study. 


\section{Findings and discussions}

During the examination of the factors related to the Western own brand emergence and growth, four reasons have been identified: Competition, concentration, legislation and technology. Although there are some similarities, the factors in China's market are very different from the ones in the Western markets, such as UK, discussed above. These differences can also support the contention that the factors leading to own brand emergence and growth can vary in the different markets. Based on the data from the interviews with the Chinese retail experts, four types of factors have been revealed: Competition, weak presence of the domestic brands, supermarket expansion and foreign retailer influence.

\subsection{Findings}

The first factor is competition. In the Western market, three types of competition exist: The competition between the manufacturers and retailers; between the discounters and retailers and among the retailers. The primary competition for the Western grocery sector is between the retailers and the manufacturers' brands (Hoch, 1996; Wileman \& Jary, 1997, Cotterill et al., 2000; Burt, 2000; Dawson, 2001; McGoldrick, 2002; Keynote, 2003; Jonas \& Roosen; 2005.). In contrast, unlike the Western retailers, the main competition in China exists among the retailers themselves (R3, R5, R7, R8; C1, C2, P2 and P3). The other two types of competition, i.e., between retailer and manufacturers brands (i.e., international and national brands) and between retailer and tertiary brands (i.e., third or fourth tiered products) have not been a threat to Chinese retailers (R2, C3). Therefore, the competition among the retailers is the main cause to develop own brands in China (R1, C2) while developing own brands may be a strategy to gain retailer differentiation.

The second factor is the weak presence of the domestic brands. After the open door policy in the Chinese retail market, international brands were introduced to the Chinese consumers (C2). However the domestic brands are still the main products in the market. In China's markets, international brands usually have a better reputation than domestic brands (R3, R6, R7, R10). This is partly due to the country of origin effect, but the weak presence of domestic brands is the main cause. This situation means that fewer national brands are available and unstable or lower quality in tertiary brands (R1, R9, C3, and P2). Although currently retailers coexist with tertiary brands, these brands will be eventually replaced by own brands because the latter do not have the bargaining power over retailers $(\mathrm{R} 3, \mathrm{R} 8)$.

The third factor is the expansion of the supermarkets. The expansion of supermarkets is one of the most important factors resulting in Chinese own brand emergence and growth (R1, R9). The expansion can be measured by two dimensions: The size or the units of the supermarkets and the sales revenue from the supermarkets (R2, R6, P3). Expanding the scope of the distribution (i.e., bigger store size or more store units) and increasing the level of the sales revenue could augment the retailer bargaining power with the own brand suppliers and investment capability in own brand production (R4, R 5 and $\mathrm{C} 1$ ). Based on the statistical data shown on Tables 2 and 3, the positive correlation between expansion and revenue is presented. The tables show that the more units the chain has, the more revenue the firm makes with the exception of 2007.

The fourth factor is the influence of foreign retailers. Foreign retailers have a direct impact on Chinese own brand's emergence and growth. From the 1970s, building own brands as one of the retailing marketing strategies has been successfully practiced in Western countries; especially in France and the UK. It has been evident that the own brand strategy could improve the profit margin and achieve a differentiation advantage. Since 1992, the Chinese retailing sector started to open its doors to foreign retailers (Chen, 2004; Li \& Fung Research Center, 2006). Internationally well-known retailers, such as Carrefour, Metro, and RT-Mart entered the Chinese retailing market (R1, R2, R9, R3, R8, R10, C1, C2, C3, P1, P2, P3). The foreign retailers have not only brought new retail formats into the Chinese market, but also introduced its management system to Chinese retail firms (P1).

\subsection{Discussions}

In the Chinese grocery sector, there are three types of competition. See Figure 1. In comparison to the Western market, international and national brands in China have absolute advantages over Chinese retailer brands. The technology level of national/international brands is very high built over years of innovation and improvement $(\mathrm{C} 1, \mathrm{R} 2)$. It is unlikely to see an increase in Chinese own brands to such a high level in a short period of time. The director of an international consulting firm (C3) stressed that in the Western countries, the main competitors of own brands were national brand manufacturers. In contrast, in China in the next five to ten years, own brands would not be strong enough to compete with these international and national brands due to the challenge of technology, such as a lack of R\&D support for technology-based innovation (R2, C3). Retailers' own brands will stay in a market position, which is much below the international and national brands for a considerable period of time (R8, C1, C2). For example, the international brand Coca-Cola and national brand Qingdao beer would not 
be challenged by the retailers' own brands (C2 and $\mathrm{C} 3$ ). In addition to the technology part of the difficulties, other reasons, such as economic status and cultural influences are also attributes hindering the penetration of the retailers' own brands.

The increase of economic status in China has influenced the consumer consumption pattern. Chinese consumers are willing to pay a higher price in order to purchase better quality products. The name brand products tend to satisfy this specific consumer requirement. Therefore, the brand consciousness has accordingly been enhanced due to the financial improvements in the consumer base. Based on the Shanghai statistical yearbook 2005, the average earnings of Shanghai employees have significantly increased over the last two decades. In 1990, the average annual income of Shanghai urban employees was 2,917 yuan, but in 2004, it increased to 24,398 yuan, which constitutes an approximately eight-fold increase from 1990 to 2004.

Strong brand consciousness has resulted in Chinese consumers purchasing international and national brands over own brands and tertiary brands. Chinese consumers have the highest brand consciousness in the world as stated by a senior manager (R1). Having a higher level of brand consciousness is a part of Chinese cultural characteristics and it is not an individual preference. Chinese consumers would pay a higher price to purchase name-branded products. The manager of a supermarket (R3) also stated that one of the best selling products in the supermarket was Coca-Cola even though its price is much higher than that of own brands or tertiary brands.

At the other end of the brand spectrum is the discounter, which is a very new retail format in China. It has not been accepted by the majority of Chinese consumers. The first discounter chain in China, Dia, opened its first four Shanghai stores in July of 2003. About $50 \%$ of the goods in the store were own labeled products sold at an average $20 \%$ to $40 \%$ lower price than that of manufacturers' brands (CCFA, 2006; R10). Some products were priced at $50 \%$ below that of the national brands (R10). Based on the report in 2006 from China Chain Franchising Association (CCFA, 2006), the sales data from Dia was not positive. The main reason for its losses was due to the resistance to the discounter's format by Shanghai consumers (CCFA, 2006). Especially, its own labeled products have not been appreciated by the consumers even though the prices are well below the national brands and lower than most of the other own brands in the retailers' chains (R7, R8, R9; C1, C2 and C3). Based on the current performance, the discounters' own labeled products have not created a threat to supermarket own brands. Chinese consumers tend to favor supermarket own brands over the discounter's labels (C1, C3). Therefore, it is unlikely that discounters, like the manufactures, will present a major competition to supermarkets' own brands in the next decade (R1, R2, R10, C2).

The interview data indicated that the major competition was the one among the retailers' own brands (R3, C1). The competition among the retailers can be further divided into three sub-groups: The competition between international and Chinese retailers; the competition among international retailers, and the competition among Chinese retailers. Based on the investigation conducted in Shanghai, the competition between international and Chinese retailers created the main threat for both types of Chinese retailers $(\mathrm{C} 2, \mathrm{P} 1)$. Own brands may serve as differentiation agent which could attract the customers to buy their products rather than their competitors' (R6, R7). Thus, the competition between the retailers may be the main reason for the appearance of own brands in a non-Western market (C1, P1, P2, P3).

In addition, there was a special type of competition, i.e. the competition between retailers and tertiary suppliers. The tertiary manufactures' products neither have the cost advantage nor quality reputation. The retailers were not going to compete with them, rather, replace them (R6, R9). Retailers' own brands can gain the cost advantage which permits the retailers to set a lower price while keep the quality assured because retailers have the direct control on own brand production (R9, R10). In a sense, these tertiary brands have created the opportunity for Chinese retailers to fill out the gap between international/national brands and discounters (C1 C2 C3). This leads to addressing the second factor: Why the weak presence of domestic brands has provided the market condition for Chinese retailers to start own brand development? The strong presence of national brands in the Western market has stimulated own brand development in order to compete with the national brands. Yet, the weak presence of domestic brands in China's market has motivated Chinese retailers to search for new sources of competitive advantage in order to compete with other retailers. To an extent, this phenomenon has given Chinese retailers an opportunity to start their own brands.

Chinese supermarkets have grown exponentially over the last decade, especially in Shanghai. These developments have been demonstrated via two aspects: The scope of distribution and the scale of the firm. The former is seen by an increase in the number of the retailer outlets and workers employed while the latter is supported by the improvement of the revenue growth. The increased retail outlets have provided advantages for promoting own brand products as in-store promotion is the main method for selling products, especially in 
China's market (Song, 2003). The expansion is another factor associated with Chinese own brand as it affects the sales volumes. During the discussion with retailers regarding the influence of the retailer growth on the retail sales, the VPs of the chains (R1, R2) provided the following observation: The greater a market share a retailer has, the easier it is for the supermarket to generate own brands' revenue (R10, C2). Expansion may also enhance the retailer's bargaining power with suppliers. The Chinese retailers have advantages in negotiating with potential own brand suppliers due to the supermarket expansion; which places the Chinese retailers in a dominant position. Therefore Chinese retailers have an opportunity to set higher requirements for the supplier, command a higher level of specification and better terms for their own brand products. For example, in order to secure the quality of the own brand products, some chains have contracted with many experienced suppliers who support their own brands with very competitive prices (R7 and R8). Expansion may positively affect the capital investment on own brands. The increase of supermarket units and sizes are positively correlated to the increase of revenues. To an extent, revenue is the key source of capital for own brand investment (R3, R9, R10, C2). The retailers $(\mathrm{R} 1, \mathrm{R} 4, \mathrm{R} 8)$ stressed repeatedly that capital could not promise the success of own brand development, but without it, building own brands could not even be considered. Hence, the expansion of the size of the supermarkets provides the favorable condition for Chinese own brands emergence and growth.

The entry of foreign retailers has the significant impact on Chinese own brands with their foreign retailing influence. Two types of influence are presented: Managerial influence and conceptual influence. Many foreign retailers have adapted their home own brand strategies to Chinese market, for example, Carrefour's own brands, Metro's Qijian, and Auchan's Big Thumb. The foreign practice of building own brand strategy has directly promoted Chinese retailers to experiment with own brands (Interviews, P3 and C2). Although foreign own brand strategy may not be fully comprehended by Chinese retailers, the approach of building own brands is accepted by Chinese retailers. Conceptual influence changes the ways of retail tradition in China. The introduction of the new retail formats and consumption concepts from the foreign retailers has the revolutionary impact on the Chinese retail industry. The foreign retailers have driven the competition in Chinese retailing market to the next level, which has encouraged the Chinese retailers to rethink what would be the preferred competitive strategies to win over the competition, including developing own brands, which may be the most efficient and effective way to gain a competitive advantage $(\mathrm{C} 1, \mathrm{C} 2, \mathrm{C} 3)$. The influence of foreign retailers is very relevant to the introduction of Chinese own brands as it has transferred the capability of producing own brands to Chinese retailers (P1, P2, P3, C3).

\section{Conclusion}

The study has revealed the possible contributing factors which explain why own brands emerged and grown in the Chinese grocery sector. These factors can be further divided into four categories: Retailer competition, the weak presence of domestic brands, supermarket expansion and foreign retailer influence. The factors discussed have created the environment and condition enabling retailers to cultivate their own brands.

Although this study is qualitative in nature, its findings do suggest a number of international and managerial implications that Western and Chinese retailers might consider when developing Chinese own brand products. First, since the factors of own brand emergence and growth are significantly different between Western and Chinese markets; the adaptation of the own brand Western strategy may be a preferred approach in a non-Western market.

Second, some of the factors that are relevant to own brands in the Western markets may not be necessary to a non-Western market. For example, retailer concentration is generally believed to be the critical factor for building strong own brands in the Western markets (Hughes, 1996; Wileman \& Jary, 1997). The Chinese grocery sector is fragmented rather than concentrated (Hsu \& Lai, 2008) but the own brands have emerged and grown. Therefore, retailer concentration may not be the necessary condition for own brands emergence and growth in a non-Western market.

Third, technology-based innovation plays a major role in Western own brand development, while most innovation in China is resource-based. This supports the theory that competitive advantage can be achieved through the firms' resources (Hunt, 2000).

Fourth, a favorable legal system protects the Western retailers while China appears to have no specific laws to support retailers. Therefore, the legal system may influence own brand development, but it may not be critical to its advent.

Fifth, the failure of discounters' labels indicates that a pure low price strategy seems not to function well in China's market. Hence, other strategic approaches, such as a mid-range pricing position may be a better solution under certain circumstances. 
Finally, the factors examined in this study are very China-specific; therefore, it could be the case that the contributing factors in non-Western markets may be country specific. The localization model may be appropriate versus globalization model in own brand strategy development for the non-Western retailers.

This study has several limitations. First, a single case design from one market, i.e., Shanghai, may produce incomplete results; therefore, multiple case designs may be considered for future study. Secondly, although the interviewees have been chosen from the different chains, the interviews conducted were limited to Chinese retail experts, which may lead to biased opinions; hence, the interviews from foreign retail experts may be necessary for further exploration. Finally, a larger size of sample may be selected as the non-Western countries have diverse markets. Thus, more investigations in other non-Western markets are highly recommended. The research question of how these factors affects the emergence and growth of Chinese own brands remains to be tested. More studies, including a quantitative approach, are suggested in order to explore other possible unknown factors which is the necessity to complete the research portfolio on own brand development in a non-Western market.

\section{References}

ACNielsen. (2009). Who will win the battle of the shelf? Branded or private label products? (September). [Online] Available: http://cn.en.acnielsen.com/site/index.shtml Retrieved on September 8, 2010.

Ailawadi, K \& Harlam, B. (2004). An empirical analysis of the determinants of retail margins: The role of store-brand share. Journal of Marketing, 68 (1): 147-165.

Ailawadi, K., Bradlow, E.T., Draganska, M., Nijs, V., Rooderkerk, R.P., Sudhir, K., Wilbur, K.C., \& Zhang, J. (2010). Empirical models of manufacturer-retailer interaction: A review and agenda for future research. Market Lett, 21:273-285.

Ailawadi, K., Pauwels, K., \& Steenkamp \& Jan-Benedict E.M. (2008). Private-label use and store loyalty, Journal of Marketing, 72 (November): 19-30.

Amrouche, N., \& Zaccour, G. (2007). Shelf space allocation of national and private brands. European Journal of Operational Research, 180(2): 648-663.

Baden-Fuller, C.W.F. (1984). The changing market share of retail brands in the UK grocery trade 1960-1980 in CESCOM-IRM. The Economics of Distribution, Franco Angeli, Milan, Ch. 9, 513-526.

Bhasin, A., Dickinson, R., \& Nandan, S. (1995). Retailer Brands: A channel perspective: The United States. Journal of Marketing Channels, 4 (4), 17-36.

Boyatzis, R.E. (1998). Transforming qualitative information: Thematic analysis and code development. Sage, London.

Burt, S., \& Davis, S. (1999). Follow my leader? Look-alike retailer brands in non-manufacturer-dominated product markets in the UK. International Review of Retail, Distribution \& Consumer Research, 9 (2), 163-185.

Burt, S., \& Mavrommatis, A. (2006). The international transfer of store brand image. International Review of Retail, Distribution and Consumer Research, September, 16 (4), 395 - 413.

Burt, S., \& Sparks, L. (1994). Structural change in grocery retailing in Great Britain: A discount reorientation? International Review of Retail Distribution and Consumer Research, 4 (2), 195-217.

Burt, S., (2000). The strategic role of retail brands in British grocery retailing. European Journal of Marketing, 34 (8), 875-890.

Business Insights, (2003). Consumer goods report: The future of private label food and drink. Growth strategies for retailers and manufacturers.

Business Insights, (2005). Consumer goods reports: Fighting private label, growth drivers, brand defense strategies and market opportunities.

CCFA. (2006). Lianhua is going to withdraw the capital from Dia. [Online] Available: http://www.Ccfa.Org.Cn/End.Jsp?Id=26440 (In Chinese), (November 18, 2007).

Chen, X.K. (2004). The evolution of Chinese commerce revolution: Format innovation, in Chain Collection: Shanghai Chain Association 10th Anniversary, 17-27, Shanghai, China (In Chinese).

China Statistical Yearbook. (2000-2006). National Bureau of Statistics of China, [Online] Available: http://www.stats-sh.gov.cn/2008shtj/wzdh/index.htm. (February 25, 2010). 
Colla, E., \& Dupuis, M. (2002). Research and managerial issues on global retail competition: Carrefour/Wal-Mart', International Journal of Retail \& Distribution Management, 30 (2/3), 103-111.

Collins, A., \& Burt, S. (2003). Market sanctions, monitoring and vertical coordination within retailer-manufacturer relationships: The case of retail brand suppliers. European Journal of Marketing, 37 (5/6), 668-689.

Consuegra, O.I. (2006). Own labels in the United Kingdom: A source of competitive advantage in retail business. Pensamiento\&Gestión, 21,114-161.

Cooper, S., and Nelson, M. (2003). Economy' line foods from our supermarkets and brand name equivalents: A comparison of their nutrient contents and cost. Journal of Human Nutrition \& Dietetics, 16 (5), 339-347.

Corstjens, J., \& Corstjens, M. (1995). Store wars: The battle for mind-space and shelf-space. Chichester, England: Wiley.

Corstjens, M., \& Lal, R. (2000). Building store loyalty through store brands. Journal of Marketing Research. August, 37 (3), 281-291.

Cotterill, R.W., Putsis, W.P. Jr., \& Dhar, R. (2000). Assessing the competitive interaction between private labels and national brands. Journal of Business, 73 (1), 109-137.

Davies, G. (1998). Retail brands and the theft of identity.International Journal of Retail and Distribution Management, 26 (4), 140-146.

Dawson, J. (1999). The evolution and future structure of retailing in Europe. In: K. Jones (Ed). The Internationalization of Retailing in Europe, Center for Study of Commercial Activity, Toronto, 1-13.

Dawson, J. (2000a.) Viewpoint: Retailer power, manufacture power, competition and some questions of economic analysis. International Journal of Retail and Distribution Management, 28 (1), 5-8.

Dawson, J. (2000b). Retailing at century end: Some challenges for management and research. International Review of Retail, Distribution and Consumer Research, 10 (2), 119-148.

Dawson, J. (2001). Strategy and opportunism in European retail internationalization. British Journal of Management, 12 (4), 253-266.

Daymon, C., \& Holloway, I. (2004). Qualitative Research Methods in Public Relations and Marketing, Communications. London: Routledge.

Dobson, P.W., Davies S.W., \& Waterson, M. (2003). The patterns and implications of increasing concentration in European food retailing. Journal of Agricultural Economics, 54 (1), 111-125.

Economist. (1995). A survey of retailing. 4 March.

Fearne, A., Duffy, R., \& Hornibrook, S. (2005). Justice in UK supermarket buyer-supplier relationships: An empirical analysis. Journal of Retail \& Distribution Management, 33 (8), 570-582.

Fernie, J., \& Pierrel, R.A. (1996). Own branding in UK and French grocery markets. Journal of Product \& Brand Management, 5 (3), 48-59.

Francis, M. (2009). Private-label NPD process improvement in the UK fast moving consumer goods industry. International Journal of Innovation Management, 13(3), 467-499.

Groznik, A., \& Heese, H. S. (2010). Supply chain interactions due to store-brand introductions: The impact of retail competition. European Journal of Operational Research, 203(3), 575-582.

Hoch, S. J. (1996). How should national brands think about private labels? Sloan Management Review, 37 (2), 89-102.

Hoch, S. J., \& Banerji, S. (1993). When do private labels succeed? Sloan Management Review, summer, 57-67.

Hogarth-Scott, S., \& Rice, S.P. (1994). The new food discounters: Are they a threat to the major multiples? International Journal of Retail \& Distribution Management, 22 (1), 20-29.

Hollingsworth, A. (2004). Case study: Increasing retail concentration, evidence from the UK food retail sector. British Food Journal, 106(8), 629-638.

Horng, C., \& Chen, W. (2007). From Contract Manufacturing to Own Brand Management: The Role of Learning and Cultural Heritage Identity. Management and Organization Review, 4(1), 109-133. 
Hsu, H.C and Lai, C.S. (2008). Examination of Factors Moderating the Success the Packaged Food Market in China of Private Label Brands: A Study of the Packaged Food Market in China. Journal of Food Products Marketing, 14 (4): 1-19.

Hughes, A. (1996). Retail restructuring and the strategic significance of food retailers', own-labels: A UK-USA comparison. Environment and Planning A, 28 (12), 201-2226.

Hui, S. K., Fader, P. S., \& Bradlow, E. T. (2009a). Path data in marketing: an integrative framework and prospectus for model-building. Marketing Science, 28(2), 320-335.

Hui, S. K., Fader, P. S., \& Bradlow, E. T. (2009b). The traveling salesman goes shopping: the systematic inefficiencies of grocery paths. Marketing Science, 28(3), 566-572.

Hunt, S.D. (2000). A general theory of competition: Resources, competence, productivity, economic growth. London: Sage.

Jonas, A., \& Roosen, J. (2005).Private labels for premium products-the example of organic food.International Journal of Retail \& Distribution Management, 33 (8), 636-653.

Keynote. (2003). Market assessment report: Supermarket own labels, April, Second Edition.

Laaksonen, H. (1994). Own brands in food retailing across Europe. Oxford: Oxford Institute of Retail Management.

Larson, J. S., \& Bradlow, E. T., \& Fader, P. (2005).An exploratory look at in-store supermarket shopping paths. International Journal of Research in Marketing, 22(4), 395-414.

Li \& Fung Research Center. (2006). China's retail sector in 2005-06, Part I: Market developments and trends. China Distributions \& Trading, May, Issue 31.

Liu, T., \& Wang, C. (2008). Factors affecting attitudes toward private labels and promoted brands. Journal of Marketing Management, 24(3/4): 283-298.

Marsden, T., \& Wrigley, N. (1996). Retailing, the food system and the regulatory state. in Retailing, Consumption and Capital: towards the New Retail Geography, eds., Wrigley N., Lowe M., London: Routledge, 33-47.

McGoldrick, P. (2002). Retail Marketing. London: McGraw Hill.

Mintel. (2005). Report: Food Retailing-UK. November 2005.

Nandan, S., \& Dickinson, R. (1994). Private brands: Major brand perspective. Journal of Consumer Marketing, $11(4), 18-28$.

Omar, O.E. (1994). Comparative product testing for own label marketing. International Journal of Retail and Distribution Management, 22 (2), 12-17.

Omar, O.E. (1995). Retail influence on food technology and innovation. International Journal of Retail and Distribution Management, 23 (3), 11-16.

Omar, O.E. (1996). Grocery purchase behavior for national and own-label brands. The Service Industries Journal, January, 16 (1), 58-66.

Pache, G. (2007). Private label development: The large food retailer faced with the supplier's opportunism. The Service Industries Journal, March, 27 (2), 175-188.

Song, Y. (2003). The challenges and opportunities of the current retail market. Internal Presentation, AC Nielson, China, Held on November 6, 2003 (In Chinese).

Steenkamp, J.B.E.M., \& Dekimpe, M.G. (1997). The increasing power of store brands: building loyalty and market share. Long Range Planning, 30 (6), 917-930.

Tarzijan, J. (2003). Private labels and retail market concentration. ABANTE, 6(1), 1-20.

Tarzijan, J. (2004). Strategic effects of private labels and horizontal integration. International Review of Retail, Distribution and Consumer Research, 14(3), 321-335.

Veloutsou, C., Gioulistanis, E., \& Moutinho, L. (2004). Own labels choice criteria and perceived characteristics in Greece and Scotland: Factors influencing the willingness to buy. Journal of Product \& Brand Management, 13 (4), 228-241. 
Verhoef, P.C., Nijssen, E.J., \& Sloot, L.M. (2002). Strategic reactions of national brand manufacturers towards private labels: An empirical study in the Netherlands. European Journal of Marketing, 36 (11/12), 1309-1326.

Ward, M. Shimshack, J. Perloff, J., \& Harris, M. (2002). Effects of the private-label invasion on the food industries. American Journal of Agricultural Economics, 84 (4), 961-973.

Wileman, A., \& Jary, M. (1997). Retail power plays: from trading to brand leadership. London: Macmillan Press Ltd.

Wu. S., \& Deng. H. (2002). Do you want a Big Mac or rice? Report on the fast food industry in China, Agriculture and Agri-Food Section: Canadian Consulate General in Shanghai. April.

Yin, R. K. (1994). Case Study Research: Design and Methods. London: Sage.

Table 1. Description of retail expert participants

\begin{tabular}{l|l|l}
\hline Interviewees & Position & Ownership/firms \\
\hline Retailer from Standard Supermarket (R1) & VP & Domestic firm \\
\hline Retailer from Standard Supermarket (R2) & VP & Domestic firm \\
\hline Retailer from Standard Supermarket (R3) & Store Manager & Domestic firm \\
\hline Retailer from Hypermarket (R4) & Store Manager & Joint Venture \\
\hline Retailer from Hypermarket (R5) & CEO & Joint Venture \\
\hline Retailer from Hypermarket (R6) & VP & Joint Venture \\
\hline Retailer from Hypermarket (R7) & VP & Joint Venture \\
\hline Retailer from warehouse club (R8) & Store Manager & Joint Venture \\
\hline Retailers from CVS (R9) & CEO & Domestic firm \\
\hline Retailers from CVS (R10) & VP & Domestic firm \\
\hline Senior Consultants (C1, C2, C3) & CEO, VP, Director & Consulting firms \\
\hline Professors (P1, P2, P3) & Dean, Chair and Faculty & Chinese universities \\
\hline
\end{tabular}

NB: R1stands for retailer1; C1 stands for consultant 1; P1 stands for professor.

Table 2. Major supermarkets outlets in shanghai 2005-2009*

\begin{tabular}{lccccc}
\hline Company/year & 2005 & 2006 & 2007 & 2008 & 2009 \\
\hline & Units & Units & Units & Units & Units \\
Lianhua Supermarket Company & 3786 & 3928 & 3774 & 3932 & 5599 \\
Shanghai Lianjia Supermarket Co.Ltd. (Carrefour) & 8 & 11 & 12 & 19 & 19 \\
RT-Mart Supermarket Company & 32 & 36 & 36 & 50 & 63 \\
Nonggongshang Supermarket Company & 1572 & 1872 & 3217 & 3354 & 3322 \\
Shanghai Lianhua Supermarket Company & 1937 & 1955 & 2108 & 1946 & 1755 \\
Metro Cash \% Carry Co Ltd. & 27 & 33 & 37 & 38 & 42 \\
Auchan Shanghai & 4 & 4 & 4 & 4 & 3 \\
\hline
\end{tabular}

Source: the data complied is based on Shanghai Statistical Yearbook (2000-2006). Accessed on August 25, 2010 http://www.stats-sh.gov.cn/2003shtj/tjnj/nj10.htm?d1=2010tjnj/C1419.htm. * *These selected Shanghai supermarkets also have their outlets in other provinces. 
Table 3. Revenues of Shanghai major supermarkets 2005-2009 in billion yuan*

\begin{tabular}{lccccc}
\hline Company/year & 2005 & 2006 & 2007 & 2008 & 2009 \\
\hline & Sales & Sales & Sales & Sales & Sales \\
Lianhua Supermarket Company & 383 & 440 & 462 & 500 & 672 \\
Shanghai Lianjia Supermarket Co.Ltd. (Carrefour) & 39 & 45 & 53 & 61 & 65 \\
RT-Mart Supermarket Company & 195 & 230 & 287 & 351 & 448 \\
Nonggongshang Supermarket Company & 175 & 196 & 221 & 267 & 267 \\
Shanghai Lianhua Supermarket Company & 170 & 150 & 156 & 150 & 150 \\
Metro Cash \% Carry Co Ltd. & 75 & 94 & 111 & 126 & 104 \\
Auchan Shanghai & 14 & 20 & 22 & 23 & 10 \\
\hline
\end{tabular}

Source: the data complied is based on Shanghai Statistical Yearbook (2000-2006). Accessed on August 25, 2010.http://www.stats-sh.gov.cn/2003shtj/tjnj/nj10.htm?d1=2010tjnj/C1419.htm.* The revenues generated from the operations in Shanghai and other provinces.

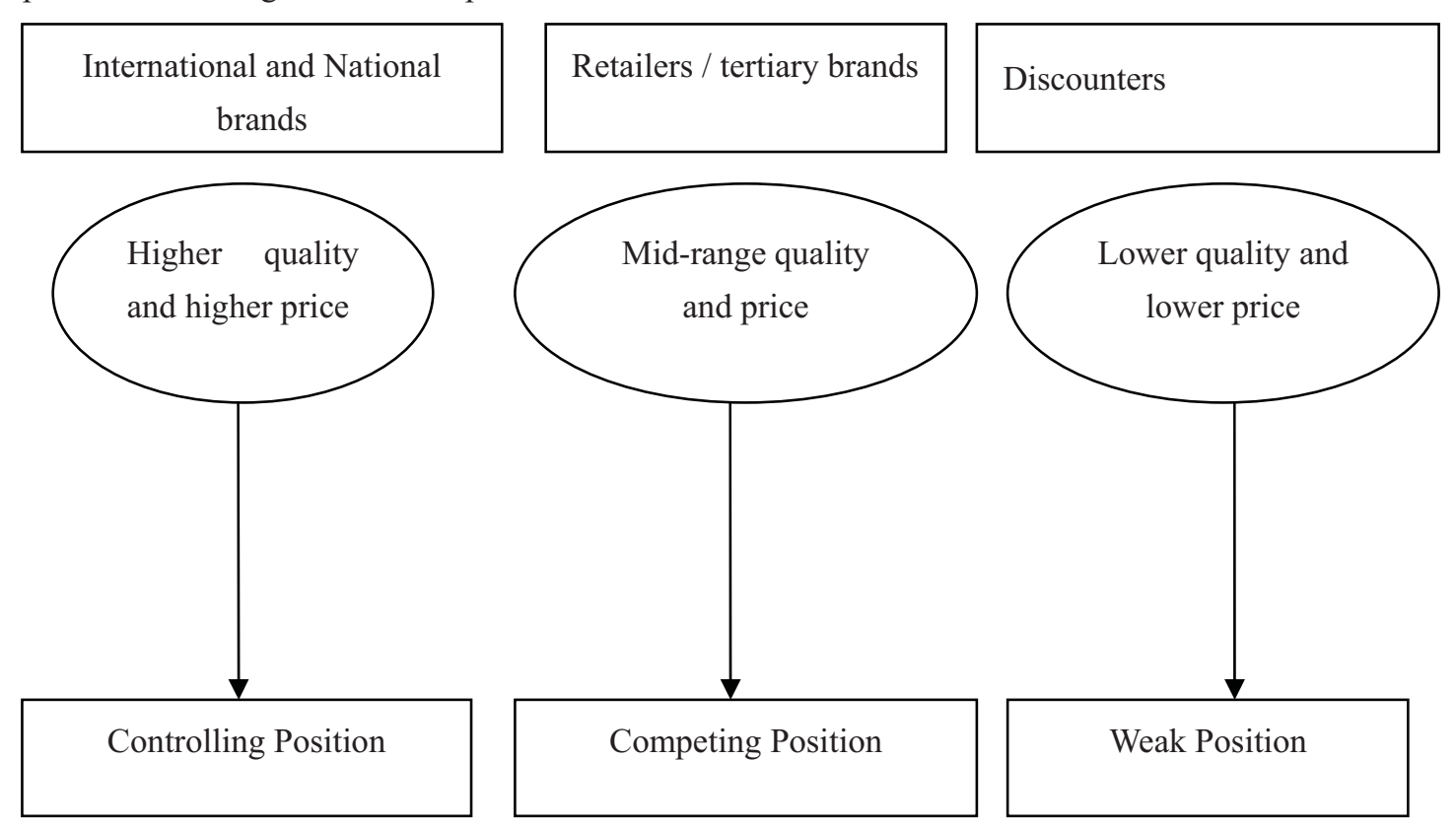

Figure 1. Brand spectrum in China's market 